\title{
Some aspects of microstructure and properties of Al-Mg alloys after shear spinning and cold rolling
}

\author{
Ljubica M. Radović ${ }^{1}$, Milutin Z. Nikačević ${ }^{1}$, Branka M. Jordović ${ }^{2}$ \\ ${ }^{1}$ Military Technical Institute, Belgrade, Serbia \\ ${ }^{2}$ Faculty of Technical Sciences, Čačak, University of Kragujevac, Serbia
}

\begin{abstract}
Three commercial Al--Mg alloys containing 3 to 6 mass\% of Mg (AlMg3, AlMg4.5Mn and AlMg6Mn) were subjected to different forming processes: shear spinning and cold rolling. The effect of $\mathrm{Mg}$ content and reduction in thickness on the tensile properties and microstructure evolution of $\mathrm{Al}-\mathrm{Mg}$ alloys were studied. Both optical (OM) and transmission electron microscopy (TEM) were used for the microstructure characterization. The results show that the addition of $\mathrm{Mg}$ in these alloys increases the yield strength (YS) and ultimate tensile strength (UTS) in both cold rolled and spun specimens. The strength of all Al-Mg alloys after shear spinning was lower compared to the strength after cold rolling for the same strain. This effect was attributed to the occurrence of dynamic recovery during shear spinning and confirmed by transmission electron microscopy.
\end{abstract}

Keywords: Al-Mg alloys, shear spinning, cold rolling, mechanical properties, microstructure, dynamic recovery.

\section{SCIENTIFIC PAPER}

UDC 669.715.017:620.18

Hem. Ind. 67 (5) 707-714 (2013)

doi: 10.2298/HEMIND121023116R

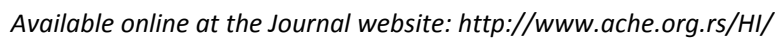

Spinning deformation processing is an advanced local metal forming process, which is widely used in many fields [1-9]. Generally, it refers to a group of processes for transforming flat sheet metal blanks or other preforms into hollow seamless, axisymmetric shapes (cylinders, cones, hemispheres or the other circular shapes) by a combination of rotation and force. The most often used terms are: conventional spinning, shear spinning (shear forming) and tube (cylindrical) flow forming. The main difference between these forming processes is in the wall thickness of the formed part. While in conventional spinning the wall thickness remains nearly constant throughout the process, in shear spinning and tube forming the wall thickness is considerably reduced.

During shear spinning a blank of the initial thickness $\left(t_{0}\right)$ is reduced to a thickness $(t)$ by a roller moving along a cone-shaped mandrel defined by an half angle, $\alpha$. During shear forming, the material is displaced along an axis parallel to the mandrel's rotational axis, as shown in Figure 1. The principal deformation process is assumed to be one of the simple shears in plane strain and hence the name, shear forming [7]. The final wall thickness $(t)$ is determined by initial thickness $\left(t_{0}\right)$, and half-angle of the mandrel $(\alpha)$, according to the "sine" law:

$t=t_{0} \sin \alpha$

Correspondence: Lj. Radović, Military Technical Institute, Belgrade, Ratka Resanovića 1, 11030 Belgrade, Serbia.

E-mail: ljubica.radovic@vti.vs.rs

Paper received: 23 October, 2012

Paper accepted: 4 December, 2012
The reduction in the wall thickness is calculated by:

$$
r=100\left(t-t_{0}\right) / t_{0}(\%)
$$

Therefore, the smaller the angle, the higher will be the reduction in wall thickness.

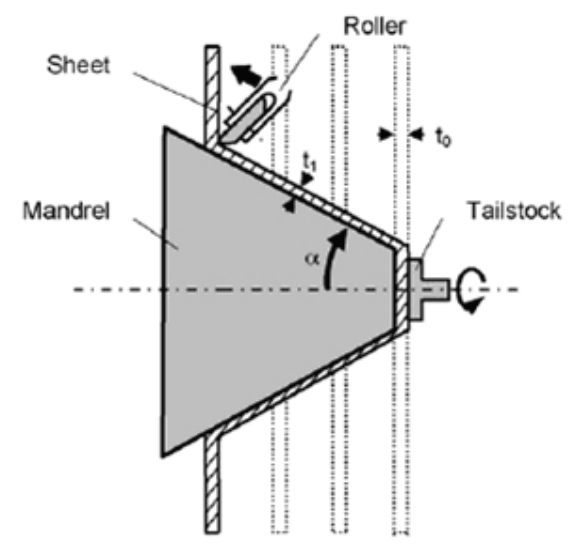

Figure 1. Schematic illustration of the shear spinning process [9].

Shear spinning and flow forming are used to manufacture the high-strength and high-precision thin-wall parts $[10,11]$. During shear spinning, the deformation of the preform takes place in localized volume in the small contact regions beneath the rollers. Therefore, the force required for deformation is significantly reduced compared to conventional press forming.

The force distribution in shear spinning has been analysed previously $[7,8,12]$. The differences between these forces and those in conventional cold rolling are evident [12-14]. Moreover, due to work hardening, significant improvement in mechanical properties can 
be achieved. Shear spinning has other advantages compared to alternative manufacturing methods (such as press forming, machining, welding, etc.) of axisymmetric sheet metal components: low forming forces, simple tools, high surface quality and dimensional accuracy, small and large scale products, shorter production times, etc. In many cases, only a single-pass is required to produce the final component, without further production steps.

The processes with wall thickness reduction are very significant especially in aerospace and automotive applications and missile parts production (ballistic cap, warhead shells, jet engine parts, rocket nose cones, rocket nozzles, tubes of the tank, liquid or gas tanks and parts of turbines and many other parts).

Aluminium alloys are the most commonly used materials for advanced applications, due to their high strength/weight ratio, corrosion resistance and good formability. Recently, some experimental studies on shear spinning and tube forming were performed on aluminium and both heat treatable and non-heat treatable aluminium alloys [15-19]. High strength aluminum alloys used in the aerospace industry exhibit problems like consistency of tolerances introduced by quenching. Using non-heat treatable alloys (solid solution hardened) this problem is eliminated. Additionally, nonheat treatable $\mathrm{Al}$ alloys have better corrosion resistance and good formability. In this respect Al-Mg alloys are the most often used among solid solution hardening alloys. Good formability of Al-Mg alloys is achieved due to high solubility of $\mathrm{Mg}$ in solid solution and the solute-dislocation interaction. The effect of solute element on work hardening characteristics and deformation microstructure has received considerable interest [20-24], but the results describing the influence of shear spinning on deformation behaviour are lacking.

The aim of this work is to evaluate the influence of processing technology (shear spinning or conventional cold rolling) on microstructure and mechanical properties of commercial Al-Mg alloys containing different contents of $\mathrm{Mg}$ and $\mathrm{Mn}$.

\section{EXPERIMENTAL}

The material used in this study was industrially produced. As received hot rolled plates were further laboratory cold rolled and fully annealed. Annealed Al-Mg alloy sheets (0-temper) with initial thickness of $3 \mathrm{~mm}$ and average grain size of approximately $15 \mu \mathrm{m}$, were finally processed by shear spinning and conventional cold rolling. The chemical compositions of the alloys are given in Table 1.

Shear spinning experiments were carried out on a LEIFELD St 400 DK spinning machine. The preforms were flat sheet metal square blanks with dimensions of $130 \mathrm{~mm} \times 130 \mathrm{~mm}$ and initial thickness $S_{0}=3 \mathrm{~mm}$. Mandrels with different angles $2 \alpha$ of $90,60,40$ and $20^{\circ}$ were used, achieving the reductions in the wall thickness of $r \approx 30,50,66$ and $84 \%$, respectively. The process parameters during shear spinning were: mandrel revolution, $n=400 \mathrm{rev} / \mathrm{min}$ for $2 \alpha$ of 90 and $60^{\circ}$, and $n=660 \mathrm{rev} / \mathrm{min}$ for $2 \alpha$ of 40 and $18^{\circ}$. The shear spun cones are presented in Figure 2.

Table 1. The chemical composition of Al-Mg alloys (mass\%)

\begin{tabular}{lcccccccc}
\hline Alloy & $\mathrm{Mg}$ & $\mathrm{Mn}$ & $\mathrm{Si}$ & $\mathrm{Cu}$ & $\mathrm{Fe}$ & $\mathrm{Zn}$ & $\mathrm{Ni}$ & $\mathrm{Al}$ \\
\hline AlMg3 & 3.10 & 0.03 & 0.09 & 0.01 & 0.31 & 0.04 & 0.01 & Bal. \\
AlMg4,5Mn & 4.50 & 0.47 & 0.16 & 0.02 & 0.42 & 0.02 & 0.01 & Bal. \\
AlMg6Mn & 6.02 & 0.54 & 0.12 & 0.015 & 0.36 & 0.07 & 0.01 & Bal. \\
\hline
\end{tabular}

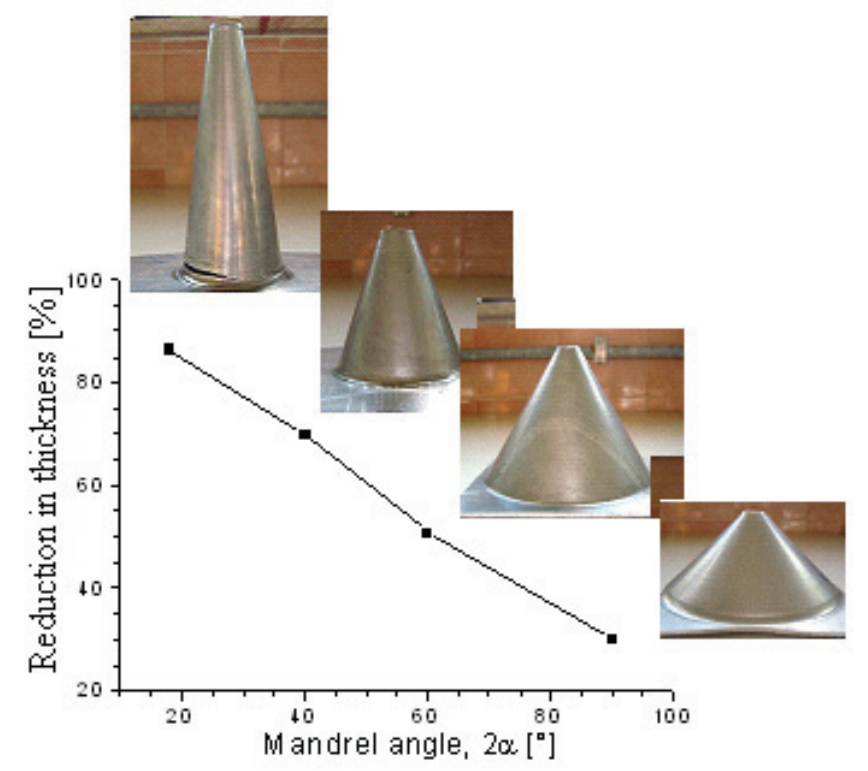

Figure 2. Effect of the mandrel angle on the reduction in the wall thickness and spun cones. 
Conventional cold rolling was performed on laboratory rolling mill at a relatively low strain rate. Tensile tests were carried out at room temperature, with strain rate of $\dot{\varepsilon}=6.7 \times 10^{-3} \mathrm{~s}^{-1}$, on a "Zwick" testing machine, using a small ASTM tension specimen with a $25 \mathrm{~mm}$ gauge length [25].

The initial microstructure of annealed specimens and microstructure after deformation by shear spinning and cold rolling was characterized by optical microscopy (OM), as well as transmission electron microscopy (TEM) using a Jeol $100 C X$ microscope operating at $100 \mathrm{kV}$. Specimens for OM were prepared by mechanical grinding and polishing techniques up to $1 \mu \mathrm{m}$ diamond paste. To reveal the grain structure, after electrolytic polishing in perchloric acid, the samples were etched in Barker's solution (25 $\mathrm{ml} \mathrm{HBF}_{4}$ (40\%), $1000 \mathrm{ml}$ distilled water). Thin foils for TEM were prepared by a twin-jet polishing technique using a mixture of $30 \%$ nitric acid and $70 \%$ methanol at $30{ }^{\circ} \mathrm{C}$. The microstructures of both spun and cold rolled specimens were characterized (OM and TEM) on the cone/sheet surface, i.e., L-T plane.

\section{RESULTS AND DISCUSSION}

The influences of the reduction in the wall thickness on the microstructure and mechanical properties of the shear spun specimens were studied compared to the cold rolled specimens.

\section{Mechanical properties}

The yield strength (YS) and the ultimate tensile strength (UTS) dependance on the reduction of Al-Mg alloys after shear spinning and cold rolling are shown in Figures 3 and 4. The YS and UTS were enhanced after shear spinning and cold rolling. They increase with increase in the reduction of thickness. This behaviour is attributed to work hardening during deformation, together with influence of the elements in solid solution (mainly $\mathrm{Mg}$ and $\mathrm{Mn}$ ), as well as second phase

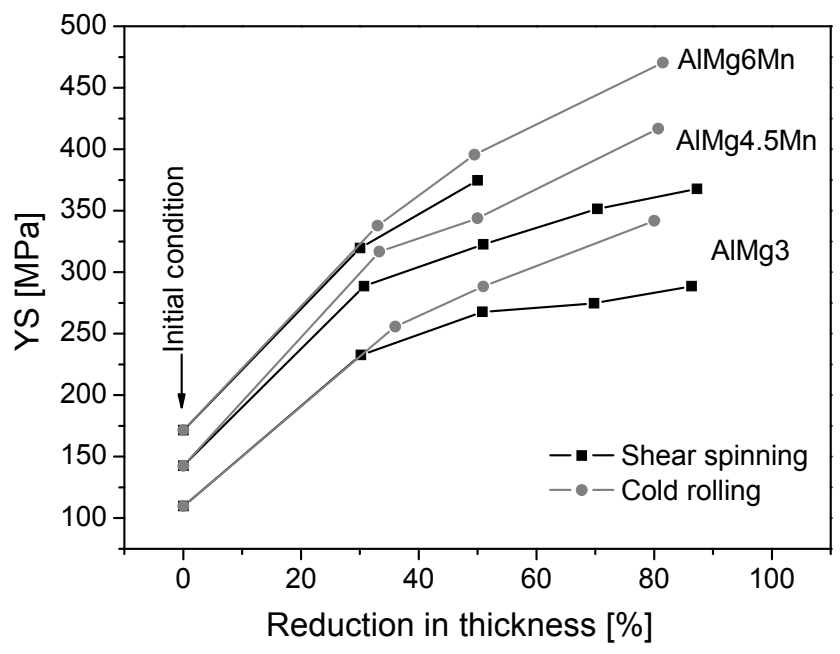

Figure 3. Effect of reduction in thickness on the yield strength (YS) of Al--Mg alloys deformed by shear spinning and cold rolling.

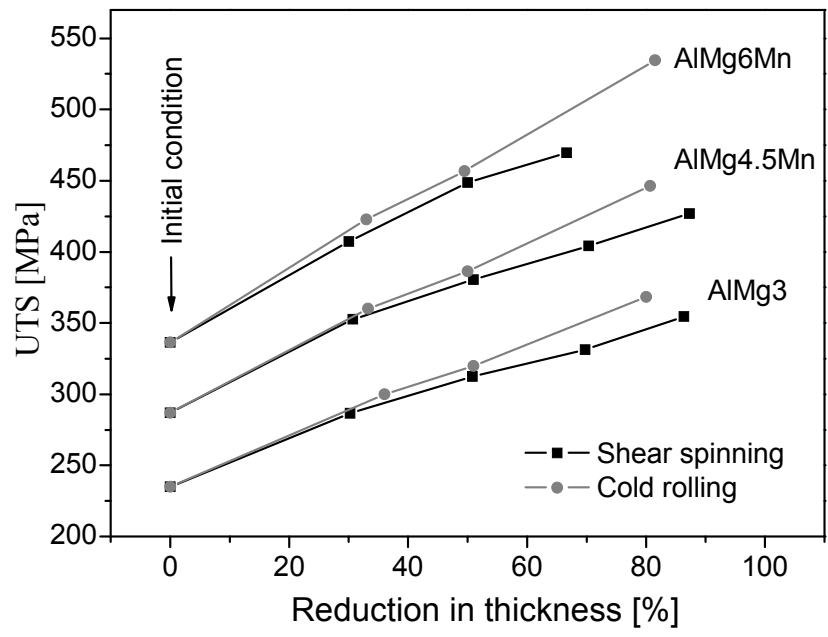

Figure 4. Effect of reduction in thickness on ultimate tensile strength (UTS) of Al-Mg alloys deformed by shear spinning and cold rolling. 
particles, as already published [20,24]. Also, both YS and UTS of the shear spun specimens were lower compared to cold rolled specimens at the same reduction. The decline in the values of YS and UTS is more pronounced with increasing reduction in all alloys.

The differences in mechanical properties of spun and cold rolled specimens indicate that some softening occured during shear spinning. During processing by shear spinning, the dynamic recovery becomes more efficient, resulting in decreased work hardening.

The effect of reduction on the total elongation during tensile tests of both shear spun and cold rolled specimens is shown in Figure 5. Elongation generally decreases with increase of applied reduction. This trend is observed in cold rolled specimens for all tested alloys. However, while elongation in the spun specimen of the AlMg3 alloy follows this trend, elongation of the other two alloys rapidly drops up to $30 \%$ reduction, decreases more slowly up to $50 \%$ reduction, and then even sligthly increases. In other words, applying higher reduction during shear spinning leads to an increase of the total elongation in AIMg4.5Mn and AIMg6Mn alloys.

About $70 \%$ reduction in the wall thickness of the cones is achieved using a mandrel with $2 \alpha=40^{\circ}$.

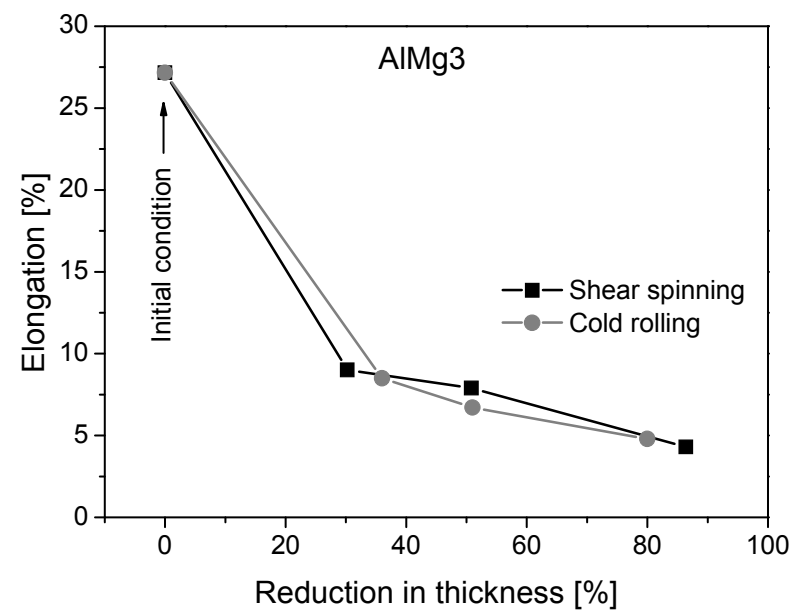

Dimensional measurement showed that the final wall thickness was less than predicted by Eq. (1), indicating that the tested material was over-reduced [26]. Overreduction has a great effect on the state of stress in the deformation zone and therefore on plasticity: overreduction increased the plasticity of a material [27].

The effect of $\mathrm{Mg}$ content on the mechanical properties of Al-Mg alloys is summarized in Figure 6. The strength increased at any given reduction with increase of $\mathrm{Mg}$ content. This behaviour is in agreement with previously published results, confirming that magnesium addition in solid solution increases considerably the work hardening ability of aluminium [19,22,24]. The solid solution hardening is a result of an interaction between the mobile dislocations and the solute atoms.

\section{Microstructure}

Microstructural characterization of the tested alloys was performed in order to understand the difference in tensile properties of spun and coled rolled specimens. An optical micrograph of the AIMg3 sample in the initial annealed condition is shown in Figure 7a. The microstructure was characterized by equiaxial grains, implying that full recristalization occured. The results of

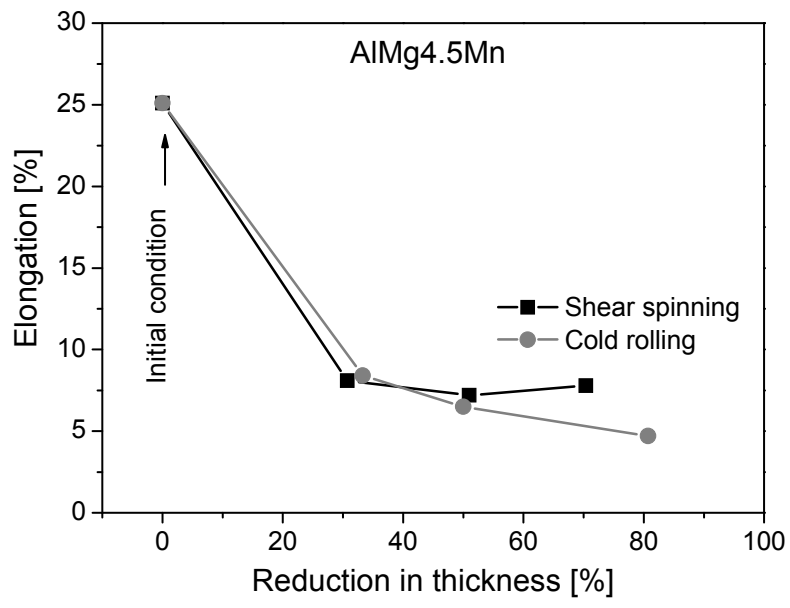

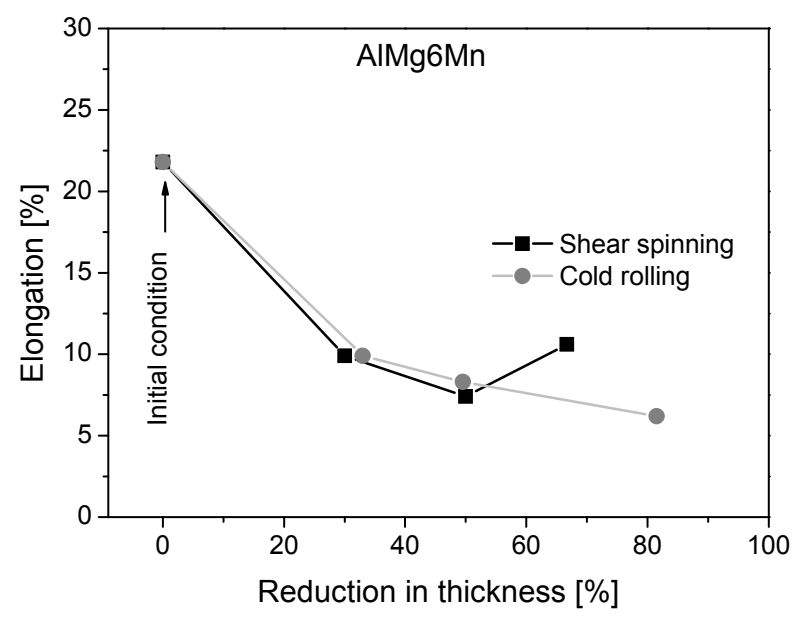

Figure 5. Effect of reduction in thickness on the total elongation of Al-Mg alloys deformed by shear spinning and cold rolling. 


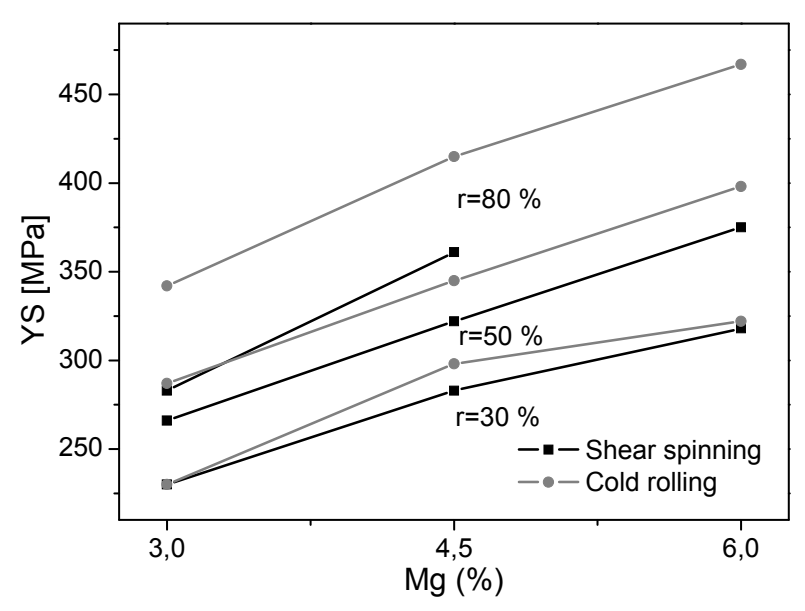

(a)

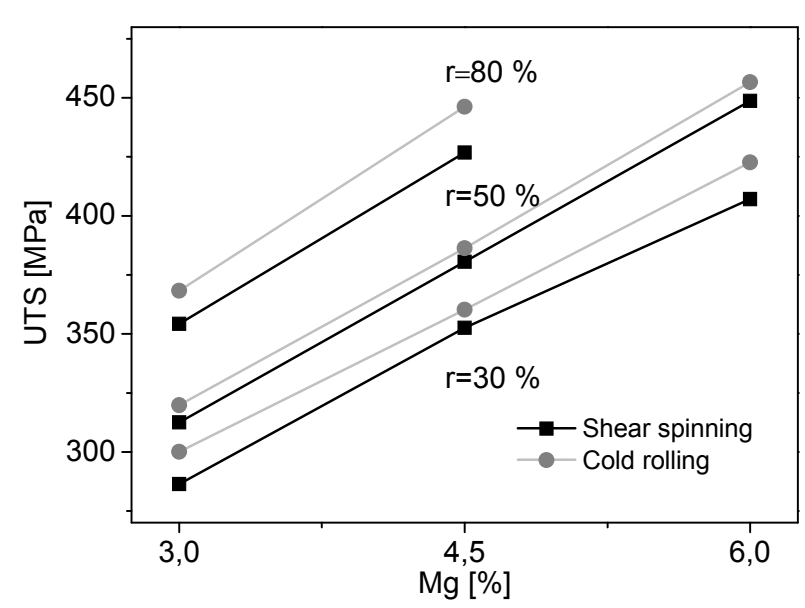

(b)

Figure 6. The influence of $\mathrm{Mg}$ content on tensile properties of Al-Mg alloys deformed by shear spinning and cold rolling. a) Yield strength (YS); b) ultimate tensile strength (UTS).

microstructural investigation of deformed Al-Mg alloys by optical microscopy showed that the microstructures after both shear spinning and cold rolling are very similar. The grains became elongated with increasing reduction in thickness during shear apinning and cold rolling. Since during shear spinning the material is displaced axially, along an axis parallel to the mandrel's rotational axis the grains become elongated (Figure 7b). Very similar microstructure is observed after cold rolling (Figure 7c). Optical micrographs of AlMg6Mn and AlMg4.5Mn alloys after shear spinning and cold rolling show similar features $[19,26]$. Therefore, based on this observation it was not possible to explain obvious differences between the applied modes of deformation.

In order to clarify difference in strength, further analysis using TEM on AIMg3 alloy was performed after deformation at applied $80 \%$ reduction by shear spinning and cold rolling (Figure 8). The substructure after shear spinning is characterized by a well-defined cell band (Figure 8a). The band walls are well-defined in one direction, while formation of cell structure by arranging dislocations into cell walls is visible in the other direction.
The TEM micrograph in Figure $8 \mathrm{~b}$ illustrates the cold rolled microstructure of AlMg3 alloy. A high level of residual stress is observed, therefore the individual dislocations are not visible. The fragmentation of the microstructure and reduction of dislocation density in the center of the fragment occured. This is evidence of the first stage of dynamic recovery, as reported previously $[20,21,23,24,28,29]$. However, well-defined cell substructure was not formed, which indicates low recovery level and significant residual stress. Well defined cell walls and subgrains, as shown in Figure $8 \mathrm{~b}$, were observed only in a few cases.

This is in good correlation with the lower values of the strength after shear spinning than cold rolling and increasing plasticity. It was supposed that the formation of the subgrains and continually increasing subgrain boundaries misorientation, due to the annihilation of dislocations, leading to grain refinement near the original grain boundaries. The newly formed grains can accommodate deformation by mechanism of grain boundary sliding and thus contribute to increased ductility [30].

The dislocation density inside the subgrains after cold rolling is much higher compared to shear spinning.

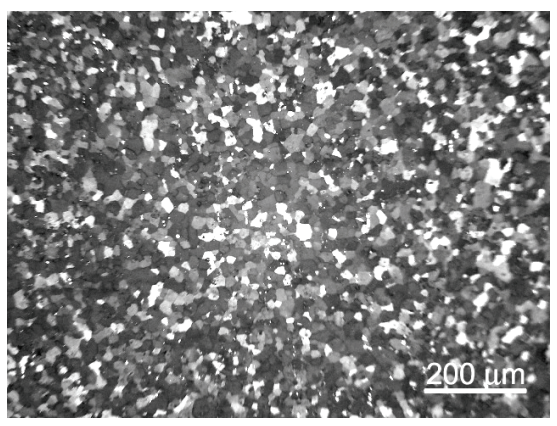

(a)

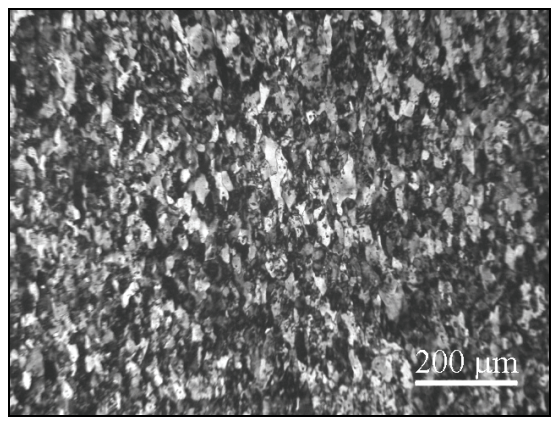

(c)

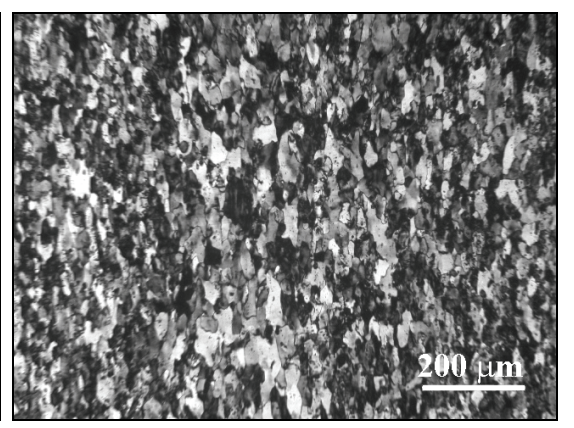

(b)

Figure 7. Optical micrographs of AIMg3 alloy. a) Initial annealed condition; b) processed by shear spinning $(r=50 \%)$; $c)$ processed by cold rolling $(r=50 \%)$. 


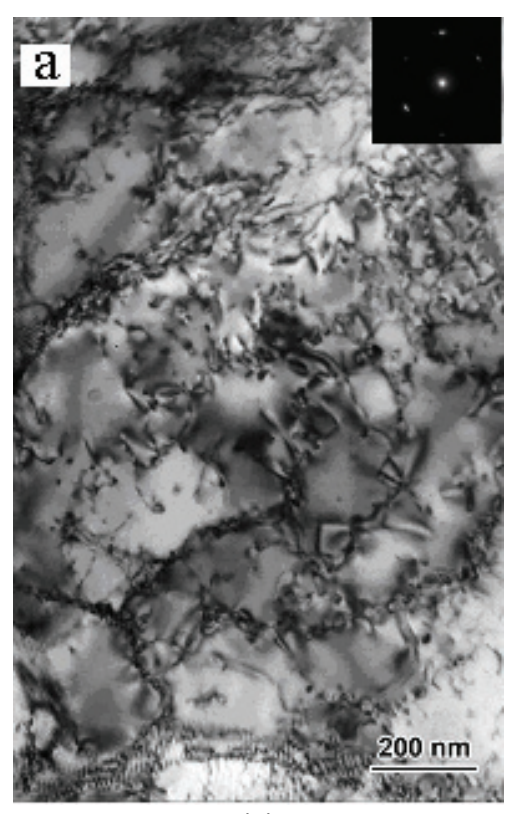

(a)

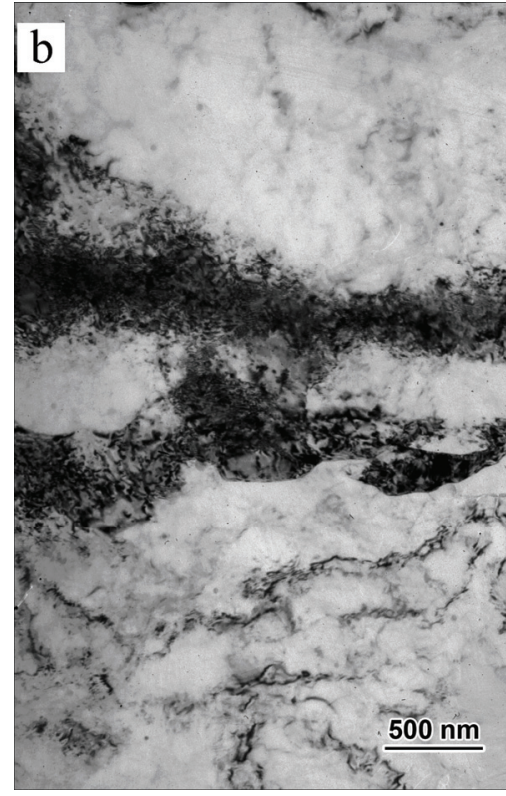

(b)

Figure 8. TEM Micrographs of dislocation substructure in AlMg3 alloy a) after shear spinning ( $r=85 \%)$ and b) after cold rolling $(r=80 \%)$.

The difference in mechanical properties is attributed to dynamic recovery in shear spun samples.

TEM microstructures obtained for AlMg3 alloy show typical recovered structure. The lower values of tensile properties (YS and UTS) of spun compared to cold rolled specimens in the other two studied alloys (AlMg4.5Mn and AlMg6Mn) can be also attributed to dynamic recovery due to supression of dynamic recrystallization in alloys with higher $\mathrm{Mg}$ content. Similar behaviour showing typically recovered microstructure is reported for $\mathrm{Al}-\mathrm{Cu}-\mathrm{Mg}$ alloy during tube spinning [31].

During dynamic recovery, simultaneosly with generation of new dislocations, rearrangement of all dislocations occurs. This feature leads to dislocation placement characterized with longer free distance for dislocation glide $[28,29]$. Easier dislocation glide results in lower strength.

\section{CONCLUSION}

Three commercial Al-Mg alloys containing 3 to 6 mass\% of $\mathrm{Mg}$ (AIMg3, AlMg4.5Mn and AlMg6Mn) were processed by shear spinning and cold rolling. The effect of $\mathrm{Mg}$ content and spinning/rolling reduction in wall thickness on the tensile properties and microstructure evolution of Al-Mg alloys was studied. Optical (OM) and transmission electron microscopy (TEM) were used for the microstructure characterization.

The tensile properties (YS and UTS) were enhanced with increasing of a reduction in thickness as well as increase of Mg content. The YS and UTS of the shear spun specimens were lower compared to cold rolled specimens at the same reductions. These differences in strength increase with increase of reduction in all alloys.

Optical micrograph revealed that the structure becomes elongated after shear spinning and cold rolling. The difference in grain size obtained in the two processes was not significant.

However, TEM characterization of spun specimens showed typical features for dynamic recovery, which were not observed in cold rolled specimens. This resulted in lower strength level of AlMg3 alloy after shear spinning compared to cold rolled specimens.

\section{Acknowledgment}

The authors are indebted to the Ministry of Education, Science and Technological Development of the Republic of Serbia for financial support through Project TR-34018.

\section{REFERENCES}

[1] http://www.acmemetalspinning.com

[2] http://www.leifeldms.de

[3] http://www.metal-spinners.co.uk

[4] http://www.precisionmetalspinning.com

[5] http://www.spincraft.net

[6] http://www.toledometalspinning.com/metal-spinninproducts

[7] S. Kalpakcioglu, A study of shear-spinnability of metals, Trans. ASME-J. Eng. Ind. 83 (1961) 478-484.

[8] S. Kobayashi, E. G. Thomsen, A theory of shear spinning of cones, Trans. ASME-J. Eng. Ind. 83 (1961) 485-495. 
[9] O. Music, J.M. Allwooda, K. Kawai, A review of the mechanics of metal spinning, J. Mater. Proc. Tech. 210 (2010) 3-23.

[10] C.C. Wong, T.A. Dean and J. Lin, A review of spinning, shear forming and flow forming processes, Int. J. Mach. Tool Manu. 43 (2003) 1419-1435.

[11] ASM Metals Handbook, Forming and Forging, Vol. 14, Ninth ed., ASM Metals Park, OH, 1988.

[12] M.-D. Chen, R.-Q. Hsu, K.-H. Fuh, An analysis of force distribution in shear spinning of cone, Int. J. Mech. Sci. 47 (2005) 902-921.

[13] B. Avitzur, Handbook of Metal-Forming Processes, John Wiley and Sons, Inc., Toronto, 1983.

[14] E. Romhanji, Mechanics and Metallurgy of Metal Forming, Faculty of Technology and Metallurgy, Belgrade, 2001.

[15] M. -D. Chen, R. -Q. Hsua, K. -H. Fuh, Effects of over-roll thickness on cone surface, J. Mater. Proc. Tech. 159 (2005) 1-8.

[16] K. Kawai, L. N. Yang, H. Kudo, A flexible shear spinning of trumcated conical shells with a general-purpose mandrel, J. Mater. Proc. Tech. 113 (2001) 28-33.

[17] S.-C. Chang, C.-C. Wang, C.-A. Huang, Y. Chang, T.-L. Chen, Fabrication of 2024 aluminum spun tube, J. Mater. Proc. Tech. 108 (2001) 294-299.

[18] S. -C. Chang, C.-C. Wang, C. -A. Huang, Y. Chang, T. -L. Chen, Fabrication of 2024 aluminum spun tube, J. Mater. Proc. Tech. 108 (2001) 294-299.

[19] Lj. Radović, M. Nikačević, B. Jordović, Deformation behaviour and microstructure evolution of AIMg6Mn alloy during shear spinning, Trans. Nonferr. Metal. Soc. 22 (2012) 991-1000.

[20] $\varnothing$. Ryen, O. Nijs, E. Sjölander, B. Holmedal, H.-E. Ekstöm, E. Nes, Strengthening Mechanisms in Solid Solution Aluminum Alloys, Metall. Mater. Trans., A 37 (2006) 1999-2006.
[21] J.M. Robinson, M.P. Shaw, Observations on deformation characteristics and microstructure in an $\mathrm{Al}-\mathrm{Mg}$ alloy during serrated flow, Mater. Sci. Eng., A 174 (1994) 1-7.

[22] D.J. Lloyd, The Deformation of Commercial AluminiumMagnesium Alloys, Metall. Trans., A 34 (1986) 1999-2009 .

[23] W. Wen, J.G.Morris, An investigation of serrated yielding in 5000 series aluminum alloys, Mater. Sci. Eng., A 354 (2003) 279-285.

[24] D.J. Lloyd, D. Kenny, The Large Strain Deformation of some Aluminium Alloys, Metall. Trans., A 13 (1982) 1445-1452.

[25] ASTM E 8-04, Standard Test Methods for Tension Testing of Metallic Materials.

[26] Lj. Radović, M, Nikačević, Osobine rotaciono valjanih konusnih delova od Al legura u funkciji sadržaja $\mathrm{Mg}$ i stepena deformacije, 3rd International Scientific Conference on Defensive Technologies, OTEH 2009, Belgrade, Military Technical Institute, Proceedings on CD, 2009.

[27] R. L. Kegg, A new test method for determination of spinnability of metals, Trans. ASME-J. Eng. Ind. 83 (1961) 119-124.

[28] F.J. Humphreys, M. Hatherely, Recrystallization and Related Annealing Phenomena, Elsevier Science Inc., New York, 1996.

[29] N. Ryum, J. D. Embury, A comment on the recrystallization behaviour of Al-Mg alloys, Scand. J. Metall. 11 (1982) 51-54.

[30] W.A. Soer, A.R. Chezan, J.Th.M. De Hosson, Deformation and reconstruction mechanisms in coarse-grained superplastic Al-Mg alloys, Acta Mater. 54 (2006) 3827$-3833$.

[31] Z.L. Hu, S.J. Yuan, X.S. Wang, G. Liu, H.J. Liu, Microstructure and mechanical properties of $\mathrm{Al}-\mathrm{Cu}-\mathrm{Mg}$ alloy tube fabricated by friction stir welding and tube spinning, Scripta Mater. 66 (2012) 427-430. 


\section{IZVOD}

\section{MIKROSTRUKTURA I SVOJSTVA AI-Mg LEGURA DEFORMISANIH ROTACIONIM VALJANEM I KONVENCIONALNIM HLADNIM VALJANJEM}

Ljubica M. Radović ${ }^{1}$, Milutin Z. Nikačević ${ }^{1}$, Branka M. Jordović ${ }^{2}$

${ }^{1}$ Vojnotehnički institut, Beograd, Srbija

${ }^{2}$ Fakultet tehničkih nauka, Čačak, Univerzitet u Kragujevcu, Srbija

(Naučni rad)

$\mathrm{U}$ ovom radu ispitane su tri komercijalne Al-Mg legure sa različitim sadržajem $\mathrm{Mg}$ od 3 do 6 mas.\% (AIMg3, AlMg4.5Mn i AlMg6Mn) su deformisane postupcima rotacionog valjanja konusa i konvencionalnim hladnim valjanjem glatkim valjcima. Korišćenjem konusnih trnova sa različitim uglovima $\left(2 \alpha=90,60,40\right.$ i $\left.18^{\circ}\right)$ pri rotacionom valjanju ostvareni su stepeni deformacije, tj. redukcije debljine zida konusa od 30 do $86 \%$. Kod Al-Mg limova koji su deformisani hladnim valjanjem glatkim valjcima, postignuti su stepeni redukcije od 30 do oko $85 \%$. Ispitan je uticaj sadržaja $\mathrm{Mg}$ i stepena deformacije na mikrostrukturne promene i zatezna svojstva Al-Mg legura. Za ispitivanje mikrostrukture primenjene su metode optičke mikroskopije (OM) i transmisione elektronske mikroskopije (TEM). Zatezne osobine su ispitane $u$ testu jednoosnim zatezanjem na sobnoj temperaturi. Rezultati su pokazali da se sa povećanjem sadržaja $\mathrm{Mg}$ u leguri i stepena redukcije napon tečenja $\left(R_{\mathrm{p} 0.2}\right)$ i zatezna čvrstoća $\left(R_{\mathrm{m}}\right)$ povećavaju, dok duktilnost pada kod oba primenjena procesa. Međutim, čvrstoća uzorka rotaciono valjanih konusa je manja u poređenju sa uzorcima koji su deformisani valjanjem glatkim valjcima sa približno istim stepenima redukcije. Pretpostavljeno je da je usled lokalizovanja deformacije pri rotacionom valjanju konusa, tj. znatno manje zone deformacije $u$ odnosu na konvencionalno hladno valjanje, došlo do oporavljanja u toku deformacije (dinamičkog oporavljanja). Optičkom mikroskopijom nisu uočene razlike u mikrostrukturi uzoraka deformisanih rotacionim valjanjem i konvencionalnim hladnim valjanjem sa približno istim stepenom redukcije. Pojava dinamičkog oporavljanja je potvrđena primenom transmisione elektronske mikroskopije.

Ključne reči: Al-Mg legure • Rotaciono valjanje konusa $\bullet$ Hladno valjanje glatkim valjcima • Mehaničke osobine • Mikrostruktura $\bullet$ Dinamičko oporavljanje 